z Halle skončil nakonec v Anglii? Není jistě náhodou, že tvůrce Mesiáše se objevuje rovněž v Nebeské propasti, konkrétně v básni Zkouška (Proba).

Myszyńskému vedle torzaické pantomimy zůstalo tedy malování a básnění. Svoji Nebeskou propast vydal Piotr spolu s matčinými básněmi pod titulem Pod věží (Pod Wieżą). Kniha je doprovázena reprodukcemi jeho olejů s krajinnou tematikou. Obdobně je tomu v jeho $\mathrm{v}$ pořadí druhé sbírce s provokujícím názvem Tančím (Tańczę), kde se jako ilustrace objevují jeho grafiky. Obojí, zejména však oleje se souboru Pod věží, má expresionistický ráz, ryze a rozmáchle expresionistický. Souvisí to nepochybně s jeho fyzickými omezeními. Je však docela možné, že zde zasahuje (proniká) i něco z jeho slezanství, jež má částečně také německé kořeny.

$\mathrm{O}$ autorově vlastní mentalitě a vzdornosti pak svědčí nejedna báseň sbírky Tančím, kupř. báseň Dům (Dom), jež končí těmito verši:

$\begin{array}{ll}\text { Bałagan i rozpacz } & \text { Neporádek a zoufalství } \\ \text { Troszkę czasu } & \text { Trocha času } \\ \text { Cisza }=\text { Zima = ni ma } & \text { Ticho = Zima = nemá } \\ \text { Mima } & \text { Mima } \\ \text { Tylko niemy gest } & \text { Pouze němé gesto } \\ \text { Poruszenia przyborów } & \text { Vzedmutí stoupající vody } \\ \text { Siedzę w ogromnym fotelu } & \\ \text { Sklerosis mól tip ex } & \text { Sedím ve velké lenošce } \\ & \text { Sklerosis mol tip ex }\end{array}$

Explicit básně je přitom příznačný, nebot' básník se v něm povznáší nad svou omezující a atakující sklerosis multiplex.

Piotrova matka Anna, podílející se na souboru Pod věží veršovanými texty, patří k lidovým písmákům slezského regionu.

František Všetička

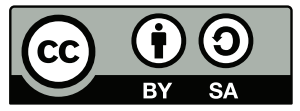

Toto dílo Ize užít v souladu s licenčními podmínkami Creative Commons BY-SA 4.0 International (<https:// creativecommons.org/licenses/by-sa/4.0/legalcode>). Uvedené se nevztahuje na díla či prvky (např. obrazovou či fotografickou dokumentaci), které jsou v díle užity na základě smluvní licence nebo výjimky či omezení príslušných práv.

\title{
Štvrtá vedecko-praktická konferencia rusistov
}

Dňa 8. 11. 2019 sa v rámci Mezinárodného knižného veltrhu „Bibliotéka“ v Bratislave z iniciatívy Velvyslanectva Ruskej federácie v Slovenskej republike a za podpory ruskej agentúry Rospečat', Ruského centra vedy a kultúry v Bratislave, Moskovskej 
štátnej univerzity M. V. Lomonosova, Ruského prekladatel'ského inštitútu a Asociácie rusistov Slovenska, uskutočnila Štvrtá vedecko-praktická konferencia rusistov venovaná metodologickým a literárnym aspektom štúdia ruského jazyka ako cudzieho. Podujatie sa uskutočnilo na pozadí zvýšeného záujmu slovenskej mládeže o štúdium ruského jazyka na Slovensku v ostatných rokoch, na základe posilnenia vzt’ahov medzi ruskými a slovenskými vzdelávacími inštitúciami a rastúceho záujmu slovenských stredoškolákov o získanie vysokoškolského vzdelania v Ruskej federácii.

Počas konferencie, ktorej pracovným jazykom bola ruština, odznela v dvoch blokoch séria zaujímavých prednášok. Prvý blok konferencie otvorila riaditelka Inštitútu ruského jazyka a kultúry Moskovskej štátnej univerzity M. V. Lomonosova, pani J.N. Kovtunová, s prednáškou zameranou na metodické postupy výučby ruského jazyka na školách a multimediálne učebné zdroje ruštiny. Nasledovala prednáška M. Bujňáka, zástupcu riaditela Školy a gymnázia pre mimoriadne nadané deti v Bratislave, ktorý sa vo svojom príspevku venoval súčasnej filozofii vyučovania cudzích jazykov na Slovensku na príklade výučby ruštiny ako cudzieho jazyka. V rámci konferencie odznela aj prednáška ruského spisovatela L. A. Danilkina, ktorý sa vo svojom vystúpení venoval problematike nového kánonu v súčasnej ruskej literatúre 21. storočia. $V$ druhom bloku konferencie vystúpili pomocníčka kultúrneho atašé Velvyslanectva RF na Slovensku A. V. Novgorodovová a hlavná odborníčka Ruského centra vedy a kultúry v Bratislave T. V. Dronská, ktoré sa venovali možnostiam štúdia ruského jazyka priamo v Rusku, či už formou študentských stáží, alebo letných škôl ruského jazyka a taktiež možnostiam pracovných pobytov pre učitelov s cielom povýšenia kvalifikácie.

Konferencie sa zúčastnili poprední ruskí a slovenskí odborníci na vyučovanie ruského jazyka ako cudzieho, pedagógovia, vedúci vzdelávacích inštitúcií, spisovatelia, zástupcovia škôl a univerzít, na ktorých sa realizuje výučba ruského jazyka.

Účastníci mali počas konferencie možnost’ bezplatne nadobudnút' metodickú a umeleckú literatúru z fondov Ruskej štátnej knižnice, vrátane nových vydaní ruských klasických diel a diel súčasných ruských autorov, publikácií pre študentov ruského jazyka a prác o súčasnej ruskej slavistike.

Igor Cintula

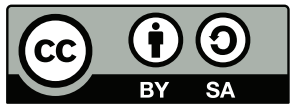

This work can be used in accordance with the Creative Commons BY-SA 4.0 International license terms and conditions (<https://creativecommons.org/licenses/by-sa/4.0/legalcode>). This does not apply to works or elements (such as images or photographs) that are used in the work under a contractual license or exception or limitation to relevant rights. 